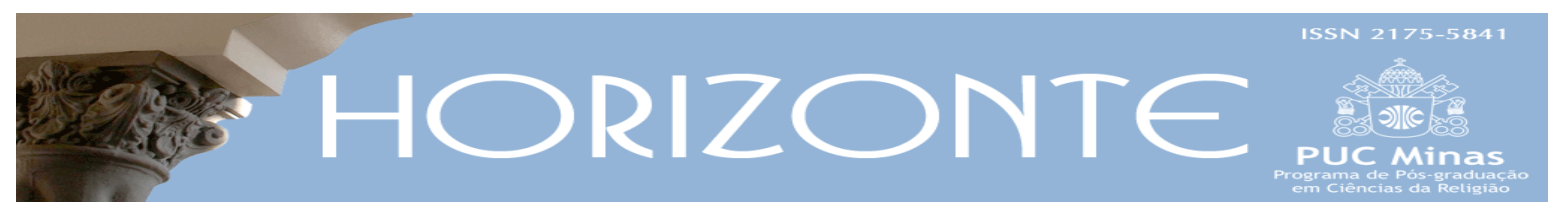

Dossiê: Política, Mídia e Religião - Artigo Original (c) ()

\title{
Minorias religiosas em Portugal: uma revisão bibliográfica
}

\author{
Religious minorities in Portugal: \\ a bibliographical review
}

José Pereira Coutinho*

\begin{abstract}
Resumo
Este artigo sobre as minorias religiosas em Portugal tem como objetivo apresentar uma revisão bibliográfica dos estudos qualitativos de cariz sociológico e/ou antropológico sobre as mesmas, contribuindo, assim, para reunir e analisar os estudos referidos, para além de avaliar, no final, o estado da arte. Para o efeito, realiza-se uma análise exaustiva dos catálogos das bibliotecas das universidades, dos sites dos centros de investigação e das plataformas de dados curriculares, para se coligir as obras de cada autor doutorado, optando-se, sempre que possível, pelas mais recentes, completas e/ou representativas do objecto estudado. Por um lado, há minorias religiosas relativamente bem analisadas, como alguns evangélicos (Igreja Evangélica de Filadélfia), alguns outros cristãos (Igreja Universal do Reino de Deus, Testemunhas de Jeová), religiões afrobrasileiras e africanas, cristãos orientais, muçulmanos, hindus e judeus. Por outro lado, há minorias religiosas totalmente por estudar, sobretudo evangélicos (e.g., Fraternal), outros cristãos (e.g., Igreja Mórmon) e minorias orientais (Budistas), cuja presença é mais significativa, ou protestantes, cuja presença é menos significativa.
\end{abstract}

Palavras-chave: Minorias religiosas. Portugal. Revisão bibliográfica.

\begin{abstract}
This article about the religious minorities in Portugal aims to present a bibliographical review of the sociological and/or anthropological qualitative studies about them, thus contributing to gather and analyze the mentioned studies, besides evaluating in the end the state of the art. For this purpose, an exhaustive analysis is carried out on the catalogs of the university libraries, the research centers' websites and the curricular data platforms, in order to collect the works of each doctoral author, opting whenever possible for the most recent, complete, and/or representative of the object studied. On the one hand, there are relatively well-analyzed religious minorities, such as some evangelicals (Evangelical Church of Philadelphia), some other Christians (Universal Church of the Kingdom of God, Jehovah's Witnesses), Afro-Brazilian and African religions, Eastern Christians, Muslims, Hindus, and Jews. On the other hand, there are religious minorities never studied, especially Evangelicals (e.g., Fraternal), other Christians (e.g., Mormon Church), and Eastern minorities (Buddhists) whose presence is most significant, or Protestants whose presence is less significant.
\end{abstract}

Keywords: Religious minorities. Portugal. Bibliographical review.

Artigo submetido em 20 de maio de 2019 e aprovado em 12 de março de 2020.

* Doutor em Sociologia pelo ISCTE-IUL (Lisboa, Portugal). Investigador integrado do Centro de Investigação em Teologia e Estudos de Religião da Universidade Católica Portuguesa (CITER-UCP). País de origem: Portugal. E-mail: jose.coutinho@numena.org.pt 


\section{Introdução}

Apesar da hegemonia religiosa católica em Portugal, explicada pelo percurso histórico português, pelo fechamento à diversidade religiosa durante séculos e pela recente abertura democrática (desde abril de 1974), as minorias religiosas têm aumentado nas últimas décadas. Explica-se, assim, que, nos últimos anos, tenham surgido vários estudos sobre algumas minorias religiosas presentes no território português. Curiosamente, não existem revisões sobre os estudos qualitativos das minorias religiosas no território português da sociologia e da antropologia da religião. Desta forma, neste artigo, pretende-se contribuir para colmatar esta lacuna, apresentando-se, primeiro, as minorias cristãs, por ser o grupo mais representativo, e, depois, as minorias não cristãs. Segundo o INE (2012, p. 530), há 81\% de católicos, $6.8 \%$ de pessoas sem religião, $8.3 \%$ pessoas que não responderam e 3.9\% de minorias religiosas, das quais 16\% são ortodoxos, $22 \%$ são protestantes, 47\% são outros cristãos, 0.8\% são judeus, 6\% são muçulmanos e $8 \%$ são outros não cristãos. No início deste artigo, antes de se apresentarem os grupos religiosos, primeiro, enunciam-se as questões teóricas e metodológicas, que guiarão a análise dos estudos, e, segundo, apresentam-se as origens das minorias estudadas, para se aferir o seu tempo de existência em território português. No final deste artigo, conclui-se, olhando para as linhas teóricas e metodológicas dominantes, vendo o que está estudado e o que falta estudar, avançando-se, depois, com futuras linhas de investigação.

\section{Questões teóricas}

Nas sociedades plurais ocidentais, onde se inclui Portugal, tornou-se paulatinamente notória a existência de minorias religiosas a par da religião dominante. Este pluralismo religioso, um dos processos da secularização, foi catalisado em Portugal a partir de abril de 1974. De monopólio religioso católico parece que avançamos para duas economias religiosas em disputa: uma religião dominante de utilidade pública e um mercado religioso incipiente (DAVIE, 2006, p. 293; 2015, p. 224). Esta tensão entre a igreja e as minorias desafiadoras foi 
analisada por Bourdieu (1971, p. 318-320), para quem os profetas das minorias contestariam o domínio daquela. Pela passagem da obrigação para o consumo, a escolha vai tomando o lugar da tradição, embora os velhos hábitos demorem a perder-se, como alerta Davie (2015, p. 224). Ao mesmo tempo, a relação de cada minoria religiosa com Portugal varia, o que obriga à diversificação do olhar. Desta forma, deste contexto plural podem surgir algumas questões em três níveis ${ }^{1}$, que serão abordadas brevemente de seguida (ver figura 1). A nível macro, a relação das minorias com o Estado, a cultura e a sociedade; a nível meso, a estrutura do mercado religioso; a nível micro, a caracterização dos fiéis; nos três níveis, os problemas decorrentes da origem externa das minorias.

A nível macro, a relação do Estado com as confissões religiosas pauta-se actualmente pela Lei de Liberdade Religiosa (Lei $n^{0} 16 / 2001$, de 22 de junho), havendo ainda a Comissão de Liberdade Religiosa (despacho de 12-02-2004), que visa apresentar pareceres e aconselhar os governos nesta matéria. Fernandes (2008, p. 207) defende que, sendo o Estado atual neutro, poderia desenvolver-se a liberdade religiosa, embora a mesma se paute pela ambiguidade decorrente da Concordata. Como refere Vilaça (2006, p. 158), para se compreender a situação actual, pode considerar-se que o jogo de forças no campo religioso tem de atender sempre o Estado, figura central, o qual prefere sempre a confissão ou confissões mais numerosas ou antigas em detrimento das mais pequenas ou recentes. Surgem, assim, questões da relação entre as confissões e o Estado central ou local na forma como a mesma se pode implementar no espaço público (locais de culto, espaços assistenciais, educativos ou culturais), nas negociações existentes para o alcançar e nas motivações reais das concessões estatais.

De um regime autoritário 'catolaicista' (CRUZ, 1999, p. 15), em que a Igreja e o Estado se entendiam e em que o ser católico seria uma obrigação social (LAGES, 1965, p. 220), passou-se para a possibilidade da pluralidade de identidades, o que levanta questões em termos culturais. Primeiro: a relação da pertença religiosa com

\footnotetext{
${ }^{1}$ Vilaça (2006, p. 114) assentou a sua análise tridimensional do pluralismo religioso em Riis (1999, p. 23), o qual adotou um raciocínio metodológico semelhante à Dobbelaere (1981; 1999).
} 
a identidade portuguesa. Sendo o catolicismo a religião dominante desde a fundação da nacionalidade portuguesa (meados do século XII), associando-se, assim, a toda a história portuguesa e, por isso, à identidade nacional, qual a extensão da relação da identidade portuguesa com o catolicismo? Podem os portugueses, sobretudo de minorias religiosas mais recentes, considerarem-se verdadeiros portugueses? Segundo: a relação da identidade nacional com as religiões minoritárias mais antigas, como o judaísmo e o islamismo. Mesmo que com a interrupção secular da sua presença, será que estas, mesmo minoritárias, são importantes para a identidade portuguesa?

A esta perspectiva societal liga-se a perspectiva organizacional e a perspectiva individual, assentes no modelo económico norte-americano (e.g., IANNACCONE, 1992; STARK; FINKE, 2000), na teoria dos campos (BOURDIEU, 1971), nas teorias da pluralização (BERGER, 1967; LUCKMANN, 1967; DOBBELAERE, 1999) e nas teorias da individualização (e.g., DOBBELAERE, 1999; HERVIEU-LÉGER, 2005). A origem externa de muitas confissões religiosas, nalguns casos associadas a minorias estrangeiras e/ou étnicas, pode catalisar questões de integração ou adaptação das mesmas à realidade portuguesa. Primeiro: ao nível macro, sobre o processo de integração junto da sociedade portuguesa (pacificamente ou com obstáculos). Segundo: ao nível meso, sobre o 'negócio' e as suas características. Terceiro: ao nível meso também, sobre as estratégias usadas pelas confissões para se integrarem e para ajudarem os seus membros a fazê-lo, assim como os trânsitos culturais e religiosos do país de origem para o país de acolhimento. Quarto: ao nível micro, sobre as novas identidades desenvolvidas, as conversões e as peregrinações associadas.

Figura 1 - Linhas teóricas sobre as minorias religiosas

\section{MACRO}

Relação com o Estado

Relação com a cultura
MESO

Negócio

Integração
MICRO

Identidades

Conversões 


\section{Questões metodológicas}

$\mathrm{Na}$ tipologia de apresentação dos grupos religiosos, há grupos que facilmente se classificam, por pertencerem a religiões distintas, como os ortodoxos, os muçulmanos, os hindus e os judeus. As dúvidas surgem com protestantes/evangélicos e outros cristãos, por a sua classificação ser mais ambígua. Nos primeiros incluem-se os grupos pertencentes ao Conselho Português de Igrejas Cristãs (COPIC), os chamados protestantes históricos, e à Aliança Evangélica Portuguesa (AEP), os denominados evangélicos. Nos outros cristãos, incluem-se as confissões que conjugam a sua matriz cristã com a não pertença ao COPIC ou à AEP, como confissões milenaristas (e.g., Testemunhas de Jeová) e confissões neopentecostais (e.g., Igreja Universal do Reino de Deus). Dentro dos outros cristãos poderiam ser incluídos os grupos africanos (religião animista dos papéis guineenses e as Igrejas Kimbanguista e Tokoísta) e afro-brasileiros (umbanda e candomblé), pela sua matriz cristã ${ }^{2}$ e pela sua ausência do COPIC ou da AEP, mas, pela existência de vários estudos sobre os mesmos e por comungarem a matriz africana, opta-se por criar este tipo.

Comparando com o Brasil, em 2010, para além de $65 \%$ de católicos e de $8 \%$ de pessoas sem religião, existem $22 \%$ de evangélicos e $5 \%$ de outras religiões, segundo o Instituto Brasileiro de Geografia e Estatística (IBGE)3. Nos evangélicos consideram-se três grupos: de missão (4\%), pentecostais (13.3\%) e não determinados (4.8\%). Nos evangélicos de missão, destaca-se a Igreja Baptista (3.7 milhões), seguida da Igreja Adventista (1.6 milhões), Igreja Luterana (1 milhão) e Igreja Presbiteriana (0.9 milhões). Nos evangélicos pentecostais, destacam-se as Assembleias de Deus (12.3 milhões), seguidas da Congregação Cristã (2.3 milhões), Igreja Universal do Reino de Deus (1.9 milhões) e Igreja do Evangelho Quadrangular (1.8 milhões). Nas outras religiões, destacam-se os Espíritas (3.9 milhões), seguidos das Testemunhas de Jeová (1.4 milhões), Umbanda e Candomblé (1.2 milhões). No Brasil, as categorias classificatórias são mais

\footnotetext{
${ }^{2}$ Embora a religião papel da Guiné-Bissau seja animista.

${ }^{3}$ Ligação: https://sidra.ibge.gov.br/tabela/137\#resultado
} 
abrangentes do que em Portugal: os evangélicos portugueses em sentido estrito referem-se somente aos membros da AEP, onde se inserem as Assembleias de Deus e os Baptistas, mas onde não se encontram os Adventistas, a Congregação Cristã e a Igreja Universal do Reino de Deus. Outro exemplo refere-se aos protestantes, que, em Portugal, se cingem somente à Igreja Metodista, Igreja Lusitana e Igreja Presbiteriana, enquanto, no Brasil, incluem também os Baptistas e os Adventistas.

A selecção dos autores, todos doutorados, realizou-se em três fases: primeiro, pelo conhecimento do autor sobre o campo; segundo, pela consulta dos centros de investigação 4 onde os autores seleccionados na primeira fase estão integrados; terceiro, pela consulta das teses de doutoramento5 em sociologia ou em antropologia sobre religião, nos catálogos/repositórios das bibliotecas das unidades de ensino onde os autores das duas fases anteriores leccionam e/ou se doutoraram $^{6}$. A seleção das obras (e dos autores) foi efetuada, em fevereiro de 2019 nos sites/páginas dos respectivos centros e nas plataformas de dados curriculares7. Destes estudos seleccionaram-se os mais recentes, mais completos e/ou mais representativos do objecto estudado, preferindo-se as teses de doutoramento publicadas em livros e afastando-se comunicações em congressos/conferências, artigos em revistas sem arbitragem científica, estudos semelhantes ou que não se encontrem disponíveis. Os trabalhos apresentados são posteriores aos doutoramentos, sendo excepcionalmente anteriores quando são dissertações de mestrado associadas às teses de doutoramento ou muito próximos do fim do doutoramento. Os estudos referem-se a análises específicas sobre grupos religiosos e não a análises generalistas sobre vários grupos religiosos assentes em dados quantitativos e/ou revisão bibliográfica (VILAÇA, 2013; MONTEIRO, 2012a/b/d).

\footnotetext{
${ }^{4}$ No ICS-UL, CITER-UCP e CRIA (Lisboa) e IS-UP (Porto), há linhas de investigação que tratam das minorias religiosas. Noutros centros nos Açores, Braga, Évora e Lisboa, com investigadores com produção em sociologia/antropologia da religião, não há actualmente linhas de investigação em religião.

${ }^{5}$ Foram usadas 48 entradas (como religião, religiosidade, etc.) cruzadas com tese/s.

${ }^{6}$ Incluem-se Universidade de Évora, Faculdade de Ciências Sociais e Humanas da Universidade Nova de Lisboa, Universidade de Lisboa (Instituto de Ciências Sociais, Instituto Superior de Ciências Sociais e Políticas, Faculdade de Psicologia), Instituto Superior de Ciências do Trabalho e da Empresa/Instituto Universitário de Lisboa, Universidade Católica Portuguesa, Universidade de Coimbra, Universidade da Beira Interior, Universidade do Porto, Universidade do Minho e Universidade dos Açores. Da análise ao catálogo da biblioteca da Universidade do Algarve, não existem teses nesta área.

${ }^{7}$ Incluem-se ORCID, ResearchGate, Academia.edu, Plataforma DeGóis e Escavador (para os doutorados brasileiros).
} 
Refira-se aqui, mas sem analisar, dissertações de mestrado em sociologia ou antropologia e dissertações de mestrado sobre minorias religiosas fora da sociologia e da antropologia. Nas dissertações de mestrado em sociologia ou antropologia (ou ciências sociais), abordam-se protestantes (FONSECA, 2015), outros cristãos (CARDOSO, 2008; CURTINHAL, 2008), religiões africanas (SANTOS, 2010), religiões afro-brasileiras (SOBROSA, 2009), muçulmanos (SANTOS, 2008) e judeus (CARVALHO, 2004). Nas dissertações de mestrado noutras áreas, abordam-se protestantes (PAULA, 2012), outros cristãos (MARQUES, 2011), muçulmanos (BATORÉU, 2007; COSTA, 2007; DIAS, 2010; RIBEIRO, 2010; SILVA, 2011; MACHADO, 2012; FERNANDES, 2015; BRANDÃO, 2016; ALMODOVAR, 2017), hindus (GALHARDO, 2005; RAFAEL, 2018) e budistas (NUNES, 2014). Há ainda uma tese de doutoramento (ciências musicais) sobre Hare Krishna (BALDELLI, 2017).

\section{Origens das minorias religiosas em Portugal}

A primeira confissão religiosa a ressurgir foi a judaica, que durante a época moderna, devido à Inquisição, tinha sido expulsa ou assimilada, havendo alguns que se adaptaram (criptojudeus). Com a tolerância pombalina pelos judeus vieram várias famílias judaicas, várias descendentes de judeus ibéricos, do Norte de África e Gibraltar para Portugal (Açores, Algarve e Lisboa) (SANTOS, 2012, p. 134-135). Somente em Lisboa se foi consolidando a sua posição: estabelecimento da comunidade judaica e espaço no cemitério inglês (1801), fundação da primeira sinagoga (1813), fundação da Comunidade Israelita de Lisboa (1853) e inauguração da sua primeira sinagoga (1904) (SANTOS, 2012, p. 136-137; 2002, p. 439-441).

$\mathrm{Na}$ fase seguinte, despontaram as primeiras confissões protestantes, associadas às comunidades anglo-saxónicas burguesas, residentes nas zonas mais prósperas, sobretudo Lisboa e Porto, mas também aos emigrantes portugueses no Brasil: na Madeira, surgiu a Igreja Presbiteriana (1838); no Porto, surgiram a Igreja Metodista (1871) e as Igrejas Baptistas (1888); em Lisboa, iniciou-se a actividade apostólica da Igreja Episcopal (Lusitana) (1839), dos Irmãos (Darbistas) 
(1877) e das Igrejas Congregacionais (1880); no Algarve, apareceu a Assembleia de Deus (1913) (VILAÇA, 2016, p. 200). Como primeiro órgão de cooperação protestante surgiu o Círculo de Oração, no Porto, em 1903, do qual resultou a Aliança Evangélica Portuguesa, com a primeira sessão plenária, em Lisboa, em 1921 (LEITE, 2012, p. 263-265). No seguimento do diálogo ecuménico preconizado pelo Concílio Vaticano II, o motor de unificação (o posicionamento em relação ao catolicismo) tornou-se o motor de discórdia, demarcando-se duas posições em relação ao diálogo com a Igreja Católica: abertura pelas correntes sinodais e fechamento pelas correntes não hierárquicas, surgindo, da primeira (1971), o Conselho Português de Igrejas Cristãs (COPIC) e, da segunda (1974), a refundada Aliança Evangélica Portuguesa (AEP) (LEITE, 2012, p. 277-279).

Em finais do século XIX e na primeira metade do século XX, foram surgindo outras confissões cristãs. Os Espíritas apareceram, em 1896, em algumas cidades do país (Lisboa, Porto, Braga e Coimbra), por portugueses vindos de França (VILAÇA, 2006, p. 178), tendo surgido outros grupos em Lisboa, os Adventistas do Sétimo Dia (1904), através de um norte-americano, e as Testemunhas de Jeová (1925), através de um canadiano (MONTEIRO, 2012b, p. 307-309; VILAÇA, 2006, p. 177-178), e no Porto, a Congregação Cristã (1938), fundada por um português emigrado do Brasil (SOUZA, 2014, p. 500). Antes da Revolução de Abril de 1974, surgiu ainda a Comunidade Islâmica de Lisboa (1968) (VAKIL, 2005, p. 2).

Com o regime democrático várias confissões religiosas apareceram ou as existentes consolidaram-se. A Igreja Ortodoxa surgiu, em 1978-1979, através de um português, monge agostinho, convertido em Paris, que de volta a Portugal desenvolveu, na zona de Lisboa (Torres Novas), uma comunidade ortodoxa, associada ao fenómeno mediatizado da 'Santa da Ladeira' (VILAÇA, 2008, p. 3536). Posteriormente, com a imigração vinda dos países da Europa de Leste, a partir da segunda metade dos anos 2000, o peso dos ortodoxos dentro da população imigrante destacou-se. Em 1975, surgiram a Igreja do Nazareno (RAMOS, 2015, p. 145) e a Igreja Evangélica de Filadélfia (BLANES, 2008, p. 30). Acrescente-se ainda 
o surgimento, em 1998, da Fraternal, que congrega igrejas pentecostais e carismáticas, um dos quatro grandes grupos da AEP.

Nos outros cristãos, surgiram a Igreja Mórmon (1975), vinda com um canadiano, a Igreja Maná (1984), fundada por um português, e a Igreja Universal do Reino de Deus (1989), trazida por um brasileiro (MONTEIRO, 2012d, p. 327; VILAÇA, 2006, p. 194). Acrescente-se ainda o surgimento da Igreja Pentecostal Deus é Amor (IPDA), em 1987 (TÉCHIO, 2011, p. 122-123), da Missão Evangélica Lusófona, em 2002 (FORMENTI, 2014, p. 161), da Assembleia de Deus Comunidade Portuguesa, em 2005 (OLIVEIRA, 2013, p. 254), e da Igreja Pentecostal das Missões, em 2007 (cisão na IPDA) (TÉCHIO, 2011, p. 140; OLIVEIRA, 2012, p. 225). As comunidades afro-brasileiras surgiram, em Portugal, nos anos 1970 (SARAIVA, 2011, p. 58; PORDEUS, 2009, p. 22), assim como as comunidades guineenses, com a sua religião papel (SARAIVA, 2008, p. 255), enquanto as igrejas africanas, de matriz cristã, apareceram, em Lisboa, a partir dos anos 1980: a Igreja Kimbanguista, nos anos 1980 (SARRÓ; BLANES, 2008, p. 849), e a Igreja Tokoísta, nos princípios dos anos 1990 (BLANES, 2013, p. 23).

Os novos movimentos religiosos surgiram nesta altura também (MONTEIRO, 2012d, p. 327): de influência cristã/protestante (Família Internacional, 1975; Igreja da Unificação, 1985), de influência oriental (Associação Internacional para a Consciência de Krishna, 1975; Meditação Transcendental, 1978; Missão da Luz Divina, anos 1980), da Nova Era (Nova Acrópole, 1979; Fraternidade Branca Universal, 1986; Centro Lusitano de Unificação Cultural, 1988; Igreja da Cientologia, 1988). Pode acrescentar-se ainda o Mahikari (1977), de influência oriental, e o Movimento Humanista (1988), da Nova Era (CRI, 1996, p. 166, 203-204). Contudo, estes movimentos desapareceram, estagnaram ou desenvolveram-se pouco até agora. Pelo contrário, as confissões milenaristas surgidas no primeiro quartel do século XX (Adventistas e Testemunhas de Jeová) ou nos anos 1970 (Mórmon) encontraram as condições necessárias para o seu florescimento (MONTEIRO, 2012b, p. 309). 
Neste período, expandiu-se também a comunidade muçulmana (VAKIL, 2005, p. 2-3): primeiro, pela consolidação da Comunidade Islâmica de Lisboa com a chegada dos retornados de Moçambique e com a política de aproximação aos países árabes (1974-1990); depois, com o surgimento dos retornados da Guiné e, mais tarde, dos imigrantes africanos e asiáticos, desligados da cultura portuguesa (1990 à actualidade). A comunidade hindu, organizada desde 1982, veio, para Portugal, em duas fases imigratórias: numa primeira fase, no início dos anos 1980, vieram de Goa e de Moçambique, sobretudo comerciantes e profissionais liberais (engenheiros, advogados) brâmanes; numa segunda fase, no final dos anos 1980, vieram da Índia, sobretudo operários não qualificados (MONTEIRO, 2012c, p. 315316). O budismo surgiu, em Portugal, em 1979, com centros em Lisboa e no Porto, consolidando-se a sua presença com a criação da União Budista Portuguesa em 1997 (TEIXEIRA, 2007, p. 231-232).

\section{Minorias religiosas em Portugal}

\subsection{Protestantes e evangélicos}

Helena Vilaça, especialista do campo protestante/evangélico, tem desenvolvido sobretudo trabalhos teóricos e/ou quantitativos sobre o mesmo. A sua tese (VILAÇA, 2006) analisou empiricamente as atitudes dos portugueses em relação ao pluralismo, tendo abordado ainda a questão da liberdade religiosa (relação Estado e confissões religiosas), os locais de culto dos evangélicos em Portugal por confissão e por região, assim como a história das minorias religiosas em Portugal, nomeadamente deste grupo, assunto retomado em Vilaça (2015). Vilaça $(2013,2016)$ tratou quantitativamente das minorias religiosas com especial destaque para os protestantes/evangélicos em Vilaça (2016). Vilaça (2017) abordou ainda a religião na cidade sobre as igrejas evangélicas emergentes num registo mais teórico com alguns exemplos ilustrativos. 
Os trabalhos académicos sobre protestantes e evangélicos ${ }^{8}$, em registo etnográfico, têm estudado a Assembleia de Deus (AD), a maior organização pentecostal do mundo, uma derivação desta, a Igreja Evangélica de Filadélfia (IEF), e a Igreja do Nazareno (IN). Rodrigues e Guerreiro (2015) estudaram a AD na Covilhã, o processo de conversão e as duas principais manifestações de fé, o baptismo das águas e do Espírito Santo, essenciais na construção identitária pentecostal. Souza (2014) analisou também a $\mathrm{AD}^{9}$ a nível nacional, abordando as resistências à sua expansão. Na sua tese de doutoramento sobre a IN, Ramos (2015, p. 269-270) defende que os pastores cabo-verdianos têm dominado nestas igrejas de norte a sul do país, trazendo consigo especificidades oriundas das suas sociabilidades, que têm marcado esta igreja, sobretudo na Área Metropolitana de Lisboa. Sobre a IEF, Donizete Rodrigues estudou-a sobretudo na Beira Interior (RODRIGUES, 2006，2013; RODRIGUES; SANTOS，2006), Blanes (2008) abordou-a na zona de Lisboa (e Madrid) na sua tese de doutoramento e Swatowiski (2010) analisou-a numa freguesia lisboeta na sua tese de doutoramento.

Os trabalhos sobre a IEF focam-se nos processos de conversão, nas mudanças socioculturais correspondentes e nas controvérsias à sua volta. A conversão ocorre pelos males físicos e espirituais, sendo a cura milagrosa e o exorcismo essenciais para reforçar aquela. A conversão conduz à mudança profunda de vida, manifestada em todos os aspectos da vida, aumentando tanto a coesão interna, pelo reforço dos valores tradicionais, como a integração social, pela redução da violência e o aumento da solidariedade, respeitabilidade, tolerância e convivialidade. Ao mesmo tempo, o culto pentecostal é apropriado pela cultura cigana, visível na música e na dança, por exemplo, sendo veículo importante de reconstrução da identidade étnica cigana. Blanes (2008, p. 236) também explorou a música nos cultos religiosos da IEF, concluindo pela sua centralidade na aprendizagem religiosa, para além da construção de ideologias identitárias e mapas topográficos morais. Para Swatowiski (2010, p. 173-174), o estigma não recai sobre a igreja em si, mas sobre o público, assentando a tentativa de reversão do mesmo

\footnotetext{
${ }^{8}$ Há ainda um estudo comparativo entre baptistas e cristãos orientais (VILAÇA, 2010) analisado neste tipo.

${ }^{9}$ Para além da Congregação Cristã, mas, para não se repetir este estudo, analisa-se nos outros cristãos.
} 
na conversão cristã, embora considere que o ostracismo se mantenha e que haja tensão nas exigências de reforma moral, sobretudo entre os mais jovens. Os estereótipos negativos confirmam-se no processo de conversão em que este se toma como purificação do ser cigano rumo à salvação.

\subsection{Outros cristãos}

Sobre outros cristãos também se destacam os trabalhos etnográficos (só se refere o método quando não o são), salientando-se as análises específicas sobre a Igreja Universal do Reino de Deus (IURD): no Brasil e em Portugal (RUUTH; RODRIGUES, 1999; MAFRA, 2002) e em análises de conteúdo dos meios de comunicação social (jornais, revistas ou programas de televisão) (GRACINO, 2011; SOUSA; RODRIGUES, 2015). Há ainda estudos que analisaram alguns grupos religiosos incluindo a IURD: teses de doutoramento sobre IURD, Testemunhas de Jeová (TJ) e outras confissões religiosas, que assentam em entrevistas na zona de Lisboa (MONTEIRO, 2005) ou em etnografia numa freguesia lisboeta (SWATOWISKI, 2010). Existem ainda estudos sobre outras igrejas pentecostais brasileiras: Congregação Cristã (CC) e Assembleia de Deus (AD), sobretudo no norte de Portugal (SOUZA, 2014), Igreja Pentecostal Deus é Amor (IPDA) em Lisboa e outros locais portugueses (TÉCHIO, 2011), dois trabalhos assentes em inquéritos e/ou entrevistas no Grande Porto (OLIVEIRA, 2012, 2013). Por fim, um estudo sobre a Missão Evangélica Lusófona (MEL) em Lisboa (FORMENTI, 2014).

Os estudos mais completos sobre a IURD são de Ruuth e Rodrigues (1999) e de Mafra (2002). O primeiro, para além de descrever sistematicamente a IURD, abordou os problemas da sua expansão tanto internos (rupturas e denúncias de dissidentes, fraudes e outras irregularidades, exaustivas campanhas de angariação e sua diminuição drástica) como externos (difamação na comunicação social, migração para outras igrejas, conflitos com os católicos, fechamento de salas de culto e recusa em abrir outras). O segundo assentou na comparação da expansão e conversão, aspectos centrais na IURD, havendo semelhanças (expansão assente na construção narrativa identitária, centralização organizacional e tecnologia 
mediática; conversão pessoal assente num encontro com Jesus; importância da centralização para a emergência de lideranças; comportamento adequado dos fiéis para obterem o sucesso) e diferenças (no Brasil, a expansão assenta na dialéctica da perseguição e, em Portugal, na perda das tradições; no Brasil, os ritos ensinam os fiéis a continuar na fé e, em Portugal, focam-se na abertura de novos ciclos) (MAFRA, 2002, p. 26-27).

Estudos de Gracino analisaram a oposição à IURD e a outras confissões. Em relação à IURD, Gracino conclui que há dois tipos de resistentes: classe média educada e anticlerical que vê o avanço da IURD como retrocesso civilizacional; pessoas frustradas com a crise económica que veem nos brasileiros uma ameaça ao emprego e à cultura (GRACINO, 2011, p. 439). Em relação à $\mathrm{CC}$ e à $\mathrm{AD}$, Gracino conclui que as oposições à sua implantação advêm do carácter destradicionalizante da mensagem pentecostal e da matriz católica que imbrica a cultura e a história locais, dificultando a penetração de corpos estranhos (SOUZA, 2014, p. 503), algo que se aplica à IURD também (GRACINO, 2011, p. 440).

Numa perspectiva próxima, apresentam-se dois trabalhos sobre as adaptações que a IURD e as TJ fazem para ser bem-sucedidas. Na sua tese sobre estigmas e estereótipos, Swatowiski (2010, p. 174-175) considera que a IURD passou de uma postura de vítima para uma atitude de conquista, tentando reforçar os seus pontos positivos, aproximando-se de uma imagem de religiosidade ou espiritualidade fora das instituições, ao mesmo tempo que tenta criar pontes com referenciais católicos difusos, no fundo, tentando caminhar da margem para o centro. Na mesma tese, a posição relativa às $\mathrm{TJ}$ difere, pois estas consideram que os estigmas e estereótipos são injustos, tomados como acções satânicas, mas ultrapassados pela elaboração de resistências morais e racionais. Encontrando a posição de Swatowiski, Sousa e Rodrigues (2015, p. 586) consideram que as crenças e práticas da IURD são produtos para salvar da concorrência nefasta, muito ao estilo deste grupo religioso, concluindo que este grupo apresenta grande capacidade adaptativa para convencer o público de que é o único capaz de confrontar as forças malignas. 
Sobre outras igrejas pentecostais brasileiras, alguns trabalhos trataram também da questão da expansão, vista na perspectiva da adaptação e/ou da integração. Téchio (2011, p. 11) considera que na transposição da IPDA para Portugal a identidade forte da mesma se mantém, apesar das várias experiências internacionais, o que a demarca de outras igrejas brasileiras pentecostais e explica o seu sucesso. A IPDA tem papel importante na manutenção e reprodução da identidade pentecostal brasileira, através das suas performances, que também estabelecem pontes para inserção na sociedade portuguesa. Oliveira estudou o papel das comunidades pentecostais brasileiras na integração dos imigrantes brasileiros. Primeiro, num artigo que compara o papel da Igreja Católica com a Igreja Pentecostal das Missões, em que a primeira não chega aos mesmos, enquanto a segunda reúne dezenas de brasileiros, que a procuram menos para ser ajudados e mais para manterem a sua identidade religiosa (OLIVEIRA, 2012, p. 230). Depois, no âmbito da sua tese, Oliveira (2013, p. 259-274) estudou o mesmo papel, agora da Assembleia de Deus Comunidade Portuguesa, concluindo que, mesmo que possa afastar os seus frequentadores da sociedade, contribui para manter a identidade religiosa e melhorar o bem-estar dos mesmos num país estrangeiro.

Por fim outros estudos focam-se nas identidades. Baseada na perspectiva peregrino versus convertido de Hervieu-Léger (2005), Monteiro (2005) desenvolveu uma análise de TJ, IURD e Centro Lusitano ${ }^{10}$, para além do movimento Nós Somos Igreja. Os membros dos dois primeiros, assinalados pela busca de uma comunidade que os integre, caracterizam-se pela figura do convertido, escolhendo a sua nova religião e vivendo-a como autêntica conversão, embora, no primeiro, haja readaptação da tradição, pelo estudo bíblico, e o segundo se foque na emoção ritual,; os dois últimos, assinalados pela busca espiritual, caracterizam-se pela figura do peregrino, construtores de um caminho autónomo e singular, embora, no primeiro, se saliente o bem-estar emocional e, no segundo, a readaptação da relação com a tradição da Igreja, (MONTEIRO, 2005, p.

\footnotetext{
${ }^{10}$ Este é o único grupo que não se enquadra em outros cristãos. Para não se criar um novo tipo (novos movimentos religiosos) foi incluído aqui, até porque o estudo trata de dois grupos de outros cristãos.
} 
437-457). Numa análise próxima, Formenti (2014, p. 311) considera que a MEL fornece um conjunto de benefícios materiais, sociais e simbólicos que ajudam a lidar com os problemas diários e a dar sentido ao mundo em que vivem, através das suas redes internacionais e do trabalho missionário, transformando os seus membros de imigrantes a missionários. Daqui decorre a aquisição de poder, que se manifesta pelo cruzamento de capital simbólico com o mapeamento do mundo, que lhes permite lidar com a vida em movimento, assim como habitar e reformular o espaço onde vivem.

\subsection{Religiões afro-brasileiras e africanas}

Os trabalhos sobre as religiões afro-brasileiras abordam a importância da cura e das adaptações sociais, nomeadamente nos rituais e na necessidade de associativismo, sendo todos de Clara Saraiva, excepto o trabalho de Ismael Pordeus. Assentam em pesquisa etnográfica, a nível nacional ou a nível local (Lisboa) (também no Brasil em SARAIVA, 2016), para além de análise de conteúdo (associativismo) feita por Saraiva (2013). Nas religiões africanas, apresentam-se dois grupos de estudos, assentes em pesquisa etnográfica em Lisboa, para além da Guiné-Bissau (no primeiro grupo), Angola e países europeus (no segundo grupo). Primeiro, os estudos de Clara Saraiva sobre a religião papel da Guiné-Bissau (SARAIVA, 2008, 2015) e sua comparação com a umbanda (SARAIVA, 2007). Segundo, estudos inseridos em três projectos coordenados por Ramon Sarró, havendo artigos sobre a Igreja Kimbanguista do Congo (SARRÓ, 2009; SARRÓ; MÉLICE, 2012; SARRÓ; SANTOS, 2011), a Igreja Tokoísta de Angola (BLANES, 2013) e ambas as igrejas (SARRÓ; BLANES, 2008, 2010).

Na análise da cura, Saraiva (2010, p. 283-284; 2011, p. 73-74; 2016, p. 205206) considera que estas religiões exemplificam a interpenetração do religioso com o terapêutico, fornecendo resposta integral a problemas somáticos, sociais, psicológicos e espirituais, ou seja, em que a cura e o bem-estar são proporcionados, resultando o sucesso, por um lado, da combinação da curandice tradicional com o catolicismo, e, por outro lado, da capacidade de manipular os deuses, para resolver 
problemas, e de desempenhar papéis religiosos, dando poder aos agentes, algo que aquelas não oferecem. Na análise das adaptações, para Pordeus (2009, p. 147-150) a passagem para outro país acarreta a negociação da entrada de uma cultura religiosa nova num país com cultura religiosa dominante, produzindo inevitavelmente adaptações para facilitar a aceitação dos convertidos, numa perspectiva de bricolage religiosa, nomeadamente nos rituais e mais especificamente no transe, tomado cá como a vontade de ser outro, de ser contra a Igreja e a sociedade. Na análise do associativismo, Saraiva (2013, p. 150-151) conclui que estas religiões se encontram a estabelecer associações para proteger os seus membros de discriminação religiosa, preconizando a necessidade de se afirmarem, de se protegerem de acusações de perigosidade e de se institucionalizarem, assente na pureza africana, fonte das mesmas.

Saraiva (2008, p. 267), analisando a recriação da identidade guineense em Lisboa assente na religião animista dos papéis, que, numa perspectiva transnacional, circula em espíritos, pessoas e bens, no mundo real, entre Guiné e Portugal e, no mundo conceptual, entre vivos e mortos, conclui que é apropriada de forma flexível para definir a sua identidade e permitir a adaptação num contexto específico. Saraiva (2015, p. 173), focando-se na questão da morte, reforça esta análise defendendo que a comunidade resulta da intersecção do mundo dos vivos com o dos mortos e que a morte serve como fonte regenerativa por despoletar as relações com o lugar de origem. Saraiva (2007, p. 190-192), comparando as diferenças das religiões africanas (animismo) e afro-brasileiras (umbanda), conclui que, embora ambas sirvam como fontes de socialização e de valores, trazendo dos seus países originais as suas crenças e rituais, só as segundas têm sucesso em angariar membros portugueses, devido à forte relação identitária, à pequenez e oralidade das primeiras em favor do cosmopolitismo, dispersão e escrita das segundas.

No âmbito do projecto 'O Atlântico cristão', Sarró e Blanes (2008, p. 852), analisaram os percursos transnacionais que vêm de Angola e do Congo e que originam o encontro religioso em Lisboa, concluindo que esta cidade voltou a ser 
uma 'dobradiça religiosa' entre as terras da Europa e as águas do Atlântico, ponto de encontro entre velhas crenças e novos missionários, urbe central para se discutir o significado do ser europeu, africano, brasileiro, cristão ou atlântico. Para Sarró e Blanes (2010, p. 151-152) as igrejas africanas têm-se adaptado à realidade lisboeta, tornando-se menos estrangeiras, invocando uma história comum com Portugal, fazendo bricolage com sucesso.

Em torno da Igreja Kimbanguista, Ramon Sarró escreveu três artigos: dois sobre a importância de Lisboa e outro sobre alguns eventos em Portugal e no Congo. Dos dois primeiros (SARRÓ, 2009, p. 116-117; SARRÓ; MÉLICE, 2012, p. 421-422), conclui-se que Lisboa tem muita importância para esta igreja, na medida em que aqui foram proclamados os seus dogmas, havendo reforço mútuo da periferia da igreja (Lisboa) e o centro (N’Kamba), ou seja, não só a periferia depende totalmente do centro, como também aquela pode reforçá-lo, pressupondo o controlo exercido sobre a mesma (periferia exemplar). No terceiro, Sarró e Santos (2011, p. 387) concluem que o enterro da mulher do líder na capital espiritual se tornou o momento escatológico de retorno, estando vários a preparar-se económica e espiritualmente, embora não se saiba o momento certo e pareça mais um projecto do que uma realidade a cumprir-se.

Na Igreja Tokoísta, as migrações e a sua influência nas reconfigurações da memória e da identidade religiosa e étnica, nomeadamente na relocalização ideológica, são analisados por Blanes (2013, p. 32), para o qual a forma como se olha de África para a Europa se altera, de forma mais universalista ou africanista, mais centrífuga ou centrípeta, podendo trazer consigo a flutuação dos significados.

\subsection{Cristãos orientais}

Helena Vilaça estudou os cristãos orientais (ortodoxos e católicos de rito bizantino), assente em entrevistas e inquérito (VILAÇA, 2008) e comparou-os com dados retirados de um inquérito a evangélicos baptistas (VILAÇA, 2010), embora com limitações pela dimensão e abrangência da amostra dos primeiros (105 
pessoas, Porto, Lisboa e Braga) e dos segundos (44 pessoas, Porto, Lisboa e Leiria). Vilaça (2008, p. 83-84) estudou sobretudo o papel da comunidade religiosa na integração e na resolução de problemas, concluindo que a confiança dos imigrantes de Leste nas instituições portuguesas reflecte o sentimento de acolhimento, sendo as comunidades religiosas importantes tanto na satisfação das suas necessidades espirituais, culturais, emocionais e materiais, como também na sua integração social, servindo ainda para a integração sistémica junto das outras instituições portuguesas, sobretudo através da Igreja Católica.

Vilaça (2010, p. 82-87) recuperou a análise da religiosidade, da reprodução da religião na diáspora e do papel da comunidade religiosa na sua integração e na resolução de problemas, concluindo que se aproximam os altos níveis de religiosidade ${ }^{11}$, a frequência regular da igreja significativamente aumentada em Portugal e a ajuda da igreja na resolução de problemas (maior em ambos a encontrar conterrâneos), enquanto as diferenças se encontram no sentimento de integração por nacionalidade (sentem-se mais integrados cristãos orientais russos e evangélicos romenos) e na ajuda da igreja (maior ajuda encontra-se nos evangélicos no relacionamento com portugueses e nos cristãos orientais quando sentem saudades do país e família).

\subsection{Muçulmanos}

No âmbito de um compêndio europeu, ao longo dos últimos anos tem sido retratada a comunidade islâmica em Portugal, em aspectos históricos, demográficos, organizacionais, educativos, culturais, cultuais e relacionais (Estado, sociedade e confissões religiosas) (sendo o último de MAPRIL ET AL., 2017). Os trabalhos sobre muçulmanos incidem sobre a integração (TIESLER, 2005), a identidade (TIESLER; CAIRNS, 2007, 2010) e a cidadania (MAPRIL, 2010, 2012b, 2014), havendo ainda as teses de Mapril (2012a), sobre identidades transnacionais de imigrantes do Bangladesh, e de Marques (2009), sobre as particularidades dos

\footnotetext{
${ }^{11}$ Existência de Deus, Importância de Deus na vida, Importância da religião na vida, Frequência regular de oração e Educação religiosa das crianças (muito importante).
} 
grupos muçulmanos em Portugal e no Brasil. Os trabalhos basearam-se em métodos diferentes: de Tiesler. em análise de conteúdo; de Mapril, em análise de conteúdo e/ou em pesquisa etnográfica em Lisboa e no Bangladesh; de Tiesler e Cairns (2007, 2010), num inquérito por questionário em Lisboa; de Marques (2009), em trabalho etnográfico nos dois países.

Ao contrário destes estudos, os de Trovão cruzaram algumas religiões distintas, nomeadamente muçulmanos de origem indo/moçambicana, para além de hindus com origem igual e de cristãos de origem cabo-verdiana, são-tomense e filipina. Como nos cristãos analisados não se refere a confissão cristã ou se refere mais do que uma (católica e evangélica) para o mesmo estudo, não se pode analisar estes estudos nas minorias cristãs. Restam, assim, as minorias muçulmanas e hindus, optando-se por referir, nos muçulmanos, os estudos em que estes entram e, nos hindus, quando aqueles não entram. Estes estudos assentaram em entrevistas e/ou pesquisa etnográfica na Grande Lisboa, abordando os jovens e a sua participação religiosa e/ou cívica (BASTOS ET AL., 2006; TROVÃO, 2012) e a influência parental/maternal nas suas identidades religiosas e cívicas (TROVÃO, $2017 \mathrm{a} / \mathrm{b})$.

Bastos et al. (2006, p. 176-177), analisando jovens ismaelitas e sunitas indianos, concluem que, embora olhem para a religião de forma mais reflexiva e individualista, tendem a acatar a autoridade familiar na sua construção identitária, para além da envolvente comunitária e amiga que contribuem para esta. Trovão (2012, p. 851), analisando jovens cristãos cabo-verdianos e são-tomenses e muçulmanos indo/moçambicanos, conclui que as identidades religiosas promovem o activismo cívico não só para quem se sente integrado, mas também para quem experimenta conflitos inter-étnicos, sendo mediado por dinâmicas próprias de género e de geração. Em dois estudos comparando alguns países incluindo Portugal, Trovão analisou famílias (pais e filhos) sunitas e ismaelitas (TROVÃO, 2017a), mães ismaelitas e hindus indo/moçambicanas e cristãs cabo-verdianas (TROVÃO, 2017b), concluindo da mesma forma que a educação religiosa assegura certos tipos de cidadania que promovem o orgulho de pertença a certa identidade 
ao mesmo que promovem identificações entre grupos ao longo de fronteiras étnicas e religiosas. Além disso, Trovão (2017a, p. 129) conclui que a educação religiosa parental fortalece a prática e a fé dos filhos, enquanto Trovão (2017b, p. 266) conclui que os recursos religiosos são usados para encorajar os filhos a empenharse na sua cidadania, sendo também convertidos em diferentes tipos de capital social e material, que, ao mesmo tempo, fortalecem a construção da sua cidadania e dos seus filhos.

Tiesler (2005, p. 845-846) considera que a nova presença islâmica deve ser reexaminada devido a quatro factores: novos padrões migratórios (inexistência de laço colonial que dificulta a legalidade e acarreta o desconhecimento da língua), maturidade da segunda geração (pode levar a processos de fortalecimento como se vê noutros países europeus), influência da agenda política internacional muito decorrente do 11/9 (ameaça do Médio Oriente) e descoberta do passado medieval islâmico (novo ponto de referência da portugalidade). Noutro registo, Tiesler e Cairns (2007, p. 232-233; 2010, p. 113-114), comparando jovens muçulmanos com jovens não muçulmanos, concluem que há poucas diferenças sobre aspectos da família, amigos, estudo e trabalho, podendo considerar-se que estão contentes com as suas vidas, confiantes no futuro, com níveis elevados de auto-estima e com vontade de ficar em Portugal, apesar da conjuntura desfavorável.

Sobre a cidadania, Mapril apresenta três estudos sobre a construção de uma cidadania europeia e moderna no âmbito de um discurso sobre o Islão antiliberal e anti-secular. Primeiro, Mapril (2010, p. 51) considera que a educação islâmica visa a criação de 'bons' muçulmanos não só em termos religiosos, mas também em termos de cidadania e pertença. Segundo, Mapril (2012b, p. 151-152) considera que os discursos contra o Islão são desconstruídos pelos líderes muçulmanos para demonstrar que liberalismo, portugalidade e Islão são compatíveis. Terceiro, conjugando as posições anteriores, Mapril (2014, p. 77) considera que, embora a educação islâmica sirva para desconstruir o discurso islamofóbico, a vontade de construir uma ética política liberal e uma cidadania portuguesa/europeia surge 
também de os líderes terem sido participantes activos na edificação de uma sociedade pós-confessional e secular no pós-25 de Abril.

Em Mapril (2012a) surgem algumas conclusões sobre as identidades bengalis. Primeiro: a mesquita bengali em Lisboa serve como espaço ordenado no meio do caos (insucesso, morte, etc.) e fonte de sentido. Segundo: os dois discursos existentes (reformista, agregado exclusivamente às escrituras como fonte do ritual, e tradicionalista, associado à tradição como fonte suplementar de ritual) dependem do contexto socioeconómico e da posição face à migração. Terceiro: o qurban (ritual sacrificial no final da peregrinação a Meca) serve para demonstrar a posição face ao projecto migratório e o seu lugar de pertença, demarcando hierarquias de chegada e de sucesso. Numa perspectiva das identidades, Marques (2009, p. 225234) conclui que o Islão se encontra em tensão pelas adaptações a novas culturas e pela sua diversidade interna, que aquilo que parece unir os muçulmanos é a existência de um habitus, princípio gerador de práticas e de representações, e que a sua capacidade expansiva, bastante promovida pelas migrações, deriva também das conversões devido ao esforço proselitista espalhado por diferentes instituições e meios.

\subsection{Hindus}

Sobre esta comunidade, apresentam-se o estudo de Monteiro (2012c), cuja informação assenta numa entrevista feita a uma especialista; a tese de doutoramento de Sant'ana (2008), que aborda alguns aspectos religiosos (alimentação e religião, espaços religiosos, centralidade da mulher na religião e sua transmissão); a tese de doutoramento de Lourenço (2009) sobre o papel da mulher na reprodução cultural hindu Estes dois últimos, de recorte etnográfico, foram aplicados na Área Metropolitana de Lisboa. Como se referiu nos muçulmanos, os trabalhos de Trovão, que reportam a pesquisa etnográfica e/ou entrevistas na Grande Lisboa (para além de Maputo e Londres em Bastos, 2006), trataram de mulheres hindus e/ou cristãs (só hindus em Bastos, 2006), sobre as mães e a 
influência da prática religiosa no trabalho e/ou família (TROVÃO ET AL., 2014 212; TROVÃO ET AL., 2015, 2017) e o seu poder nas tradições hindus (BASTOS, 2006).

Segundo Sant'Ana (2008, p. 247), os templos hindus têm várias funções: lugares de ritual e de oração, espaços socializadores das gerações mais novas, locais de entreajuda para além da família ou casta, geradores de redes de interconhecimento dos vários hindus dispersos na malha urbana. Embora as grandes festas se desenrolem nos templos, as práticas religiosas hindus são feitas sobretudo em casa, onde domina a mulher (MONTEIRO, 2012c, p. 318), desenrolando-se terapias de prevenção e cura de mau-olhado, feitiçaria e possessão, num ambiente iconográfico sincrético (hindu e cristão), onde Nossa Senhora de Fátima se apresenta nos altares ao lado das deusas hindus (SANT'ANA, 2008, p. 252-253). Segundo Bastos (2006, p. 150), o manejo feminino da possessão tem sido importante para resistir contra a consolidação de oposições identitárias rígidas e irreversíveis da população hindu, enquanto a hegemonia da figura divina materna e a atribuição de poderes mágicos/religiosos às mulheres/mães terrenas parece estimular as inter-penetrações religiosas e cumplicidades inter-religiosas, nomeadamente na questão de Fátima.

Lourenço (2009) vai ao encontro das posições anteriores. Lourenço (2009, p. 196-201) parte da noção de diáspora como forma de reprodução cultural, nomeadamente em termos de religião e género. O hinduísmo em diáspora é uma religião em mudança, envolvendo adaptações à sociedade envolvente e a revitalização de elementos tradicionais. A articulação entre género e religião oferece novas possibilidades, como a adoção por mulheres de tarefas rituais habitualmente atribuídas aos homens. A passagem da sua acção da esfera doméstica para o espaço público permite a mudança de estatuto, a maior abertura à sociabilização e ao menor controlo das suas acções. Esta tomada de poder oferece às mulheres a possibilidade de dar continuidade às tradições dos seus antepassados juntos dos mais novos. Esta vontade de autonomia expressa-se nas práticas

\footnotetext{
${ }^{12}$ Este trabalho também incluiu mulheres muçulmanas ismaelitas, mas, por tratar de tema igual aos outros dois, considera-se aqui.
} 
corporais, como o vestir, o dançar, o cantar e o brincar, em que se libertam da dominação masculina, embora esta vontade se encontre sobretudo nas mais novas, notando-se tensão com as gerações mais velhas.

Trovão et al. (2014, p. 116), analisando mulheres muçulmanas ismaelitas e hindus de Moçambique e cristãs de São Tomé, concluem que a participação religiosa gera capital social, que se converte em recursos para reconciliar trabalho e família, mitigando as vulnerabilidades ou despoletando resultados benéficos que afectam as vidas das famílias no curto e longo prazo. Os dois estudos seguintes reforçam esta conclusão final, acrescentando outros aspectos. Trovão et al. (2015, p. 325), analisando mulheres hindus indo/moçambicanas, cristãs são-tomenses e filipinas, concluem também que estes três grupos usam a participação religiosa para explorar tácticas, capitais sociais, espaços de mobilidade e para negociar sem subverter dinâmicas familiares desiguais. Trovão et al. (2017, p. 162), analisando os mesmos grupos, concluem igualmente que a participação religiosa lhes fornece variedade de recursos expressivos e de suporte que garantem o cumprimento das responsabilidades de género e maternas.

\subsection{Judeus}

$\mathrm{Na}$ sua dissertação de mestrado (2000) e tese de doutoramento (2008), Marina Pignatelli, assente em pesquisa etnográfica, estudou a Comunidade Israelita de Lisboa (CIL). Pignatelli (2000) caracterizou a CIL, analisando a história da saga dos judeus de Lisboa desde a fundação até agora, as suas características sociodemográficas (sexo, idade, estado civil, instrução, profissão, área de residência) e étnicas (manifestações culturais preferenciais: língua, alimentação, indumentária, literatura e imprensa, música, dança e arte, objectos tradicionais; religiosidade: ciclo de vida, festividades celebradas, sinagoga, culto doméstico). Pignatelli (2008) caracterizou novamente a CIL, analisando interioridades e exterioridades da mesma: primeiro: família e parentesco, alianças e casamentos, lugar doméstico, estrutura da CIL, instituições étnicas e espaços comunitários; segundo: relações dos judeus da CIL com os outros judeus 
portugueses, relações dos judeus da CIL a nível internacional, a CIL e a sociedade de acolhimento, os não judeus e a CIL. A segunda parte do trabalho resume-se ao seguinte: a relação da CIL com a sociedade é geralmente boa, embora restrita a contactos estabelecidos nas escolas e nos meios profissionais, como a ligações familiares, devido às assimilações familiares; as relações inter-religiosas são cordiais; por vezes, a ignorância de não judeus conduz a algum anti-semitismo; a relação da CIL com as outras comunidades judaicas limita-se a locais e momentos simbólicos judaicos, onde a CIL lidera pela sua antiguidade e dimensão, enquanto as relações com judeus estrangeiros são estreitas e frequentes.

\section{Conclusões}

A análise das minorias religiosas demonstra a sua grande diversidade, apesar do seu peso relativo diminuto. Nos protestantes e evangélicos, existem estudos sobre a Igreja Evangélica de Filadélfia (IEF), associada à minoria cigana, por Donizete Rodrigues, Ruy Blanes e Claudia Swatowiski; a Assembleia de Deus (AD), por Donizete Rodrigues e Paulo Gracino Souza; e a Igreja do Nazareno (IN), por Max Ramos. Nos outros cristãos, há trabalhos sobre a Igreja Universal do Reino de Deus (IURD) (Donizete Rodrigues, Clara Mafra e Paulo Gracino Souza), a IURD e Testemunhas de Jeová (TJ) (Teresa Monteiro e Claudia Swatowiski) e outras confissões cristãs (Paulo Gracino Souza, Káchia Téchio, Maria J. Oliveira, Ambra Formenti). Nas religiões afro-brasileiras, existem os trabalhos de Clara Saraiva e de Ismael Pordeus, enquanto, nas religiões africanas, existem os trabalhos de Ramon Sarró e Ruy Blanes, para além de Clara Saraiva. Nos cristãos orientais, há os dois estudos de Helena Vilaça. Nos muçulmanos, demarcam-se os trabalhos de José Mapril, para além de Susana Trovão, Nina Tiesler e Vera Marques. Nos hindus, destacam-se os trabalhos de Helena Sant'Ana, Inês Lourenço e Susana Trovão. Nos judeus, há dois estudos de Marina Pignatelli. Destes vinte e um autores, doze são doutorados em antropologia e sete em sociologia (ainda uma em ciências sociais e outra em ciências comparadas das religiões). 
Para além das características internas das confissões religiosas, que os estudos habitualmente trazem, eles podem resumir-se nalgumas linhas teóricas. Primeiro: a relação do Estado com as confissões religiosas tem sido abordada por Vilaça (mais focada nos protestantes e evangélicos) e por Mapril sobre os muçulmanos (na publicação anual). Segundo: a relação de algumas confissões religiosas com a cultura nacional levanta a questão da identidade religiosa e cidadania, temas abordados nos trabalhos sobre muçulmanos. Terceiro: a integração das confissões na sociedade portuguesa levanta questões societais (polémicas), como nos evangélicos (AD, IEF) e outros cristãos (IURD, Congregação Cristã, TJ). Quarto: a existência de mercado religioso levanta a questão dos modelos de negócio, como na IURD. Quinto: a integração levanta também questões organizacionais, nas estratégias usadas pelas confissões para se integrarem e para ajudarem os seus membros a fazê-lo e/ou nos trânsitos culturais e religiosos do país de origem para o país de acolhimento, como nos evangélicos (IN), outros cristãos (IURD, Igreja Pentecostal Deus é Amor, Igreja Pentecostal das Missões, Assembleia de Deus Comunidade Portuguesa), religiões afro-brasileiras, religiões africanas, cristãos orientais, muçulmanos, hindus e judeus. Sexto: a conversão, o seu significado, as suas motivações (cura, salvação), as suas consequências e as identidades associadas estão presentes nos trabalhos sobre evangélicos (IEF e AD), outros cristãos (IURD, TJ, Missão Evangélica Lusófona), religiões afro-brasileiras e muçulmanos.

Em termos metodológicos, sobressaem as pesquisas etnográficas em todos os grupos estudados (excepto nos cristãos orientais), havendo ainda análises de conteúdo (discursivas ou imagéticas) nos outros cristãos, religiões afro-brasileiras e muçulmanos, entrevistas nos cristãos orientais, outros cristãos, muçulmanos e hindus, e inquéritos nos cristãos orientais, outros cristãos e muçulmanos. Ao contrário dos estudos sociológicos, que produzem retratos mais generalistas das realidades estudadas, os estudos antropológicos aprofundam-nas, o que as obriga a circunscrevê-las, daí que estes estudos se centrem em localidades ou zonas, salvo poucas excepções. Excepto alguns trabalhos sobre evangélicos, outros cristãos e cristãos orientais, todos os outros estudos decorreram exclusivamente em Lisboa 
ou na sua área metropolitana, havendo ainda bastantes casos fora de Portugal, nomeadamente nos países de origem das religiões, para aprofundar ou comparar.

O que falta estudar então? Em termos de grupos religiosos, faltam estudos sobre os protestantes e evangélicos na sua quase totalidade (sobretudo sobre os grupos mais numerosos como Fraternal, Baptistas e Irmãos; sobre outros cristãos (sobretudo sobre os grupos mais numerosos como Adventistas, Igreja Mórmon, Igreja Maná e Espíritas); sobre religiões orientais, como budistas. Em termos teóricos, certamente que as prioridades analíticas variam. Por exemplo, enquanto para confissões que olham para a religião como 'negócio' como a IURD, a análise do mesmo faz muito sentido, ao contrário de confissões que se reproduzem sobretudo por herança, como nos ortodoxos. Enquanto na questão da integração há mais trabalhos, as outras questões têm sido menos tratadas, o que indicia linhas por desenvolver. Em termos metodológicos, seria interessante apresentar-se estudos de cariz quantitativo de forma a oferecer-se imagens mais globais das confissões religiosas ou tentar replicar a nível nacional a abrangência de estudos locais.

\section{REFERÊNCIAS}

ALMODOVAR, L. Em África todos são Mamadou - é o nome do profeta em africano: pertenças múltiplas numa associação islâmica na linha de Sintra. Lisboa, 2017. Dissertação (Mestrado em Migrações, Inter-etnicidades e Transnacionalismo) - FCSHUNL.

BALDELLI, D. Práticas espirituais e expressivas num contexto migratório: uma etnografia do Movimento Hare Krishna na cidade de Lisboa. Lisboa, 2017. Tese (Doutoramento em Ciências Musicais) - FCSH-UNL.

BASTOS, S.P. A separação é tão ilusória como a ideia de que o espaço dentro de um pote é distinto do espaço à sua volta: sobre o poder das tradições expressivas das migrantes hindus. In: BASTOS, S.P.; BASTOS, J.G.P. (orgs.). Filhos diferentes de deuses diferentes. Lisboa: ACIME, 2006, p. 129-151. 
BASTOS, S.P.; COSTA, A.; BATORÉU, F. Construindo um modo pessoal de se dizerem muçulmanos e portugueses: o caso dos jovens ismaelitas e sunitas indianos de Lisboa. In: BASTOS, S.P.; BASTOS, J.G.P. Bastos (orgs.). Filhos diferentes de deuses diferentes. Lisboa: ACIME, 2006, p. 153-177.

BATORÉU, F. Enquanto muçulmanos e como portugueses a religião não foi um problema: um contributo para o estudo das estratégias de inserção social diferenciada dos muçulmanos sunitas de origem indiana em Portugal. Lisboa, 2007. Tese (Mestrado em Migrações, Minorias Étnicas e Transnacionalismo) - FCSH-UNL.

BERGER, P.L. Sacred canopy. Elements of a sociological theory of religion. Garden City (NY): Doubleday, 1967.

BLANES, R.L. Os aleluias: ciganos evangélicos e música. Lisboa: ICS, 2008.

BLANES, R.L. Prophetic visions of Europe: Rethinking place and belonging among Angolan Christians in Lisbon. In: BLANES, R.; MAPRIL, J. (eds.). Sites and Politics of Religious Diversity in Southern Europe. The best of all gods. Leiden: Brill, 2013, p. 19-36.

BOURDIEU, P. Génese et structure du champ religieux. Revue Française de Sociologie, v. 12, n. 3, p. 295-334, 1971.

BRANDÃO, I.M.C. Deuses em movimento: o caso dos muçulmanos guineenses em Lisboa. Lisboa, 2016. Tese (Mestrado em Migrações, Inter-etnicidades e Transnacionalismo) - FCSH-UNL.

CARDOSO, A.F.S.P. Nos trilhos da individualização religiosa: um estudo de caso sobre duas comunidades religiosas sociologicamente distintas. Porto, 2008. Dissertação (Mestrado em Sociologia) - FL-UP.

CARVALHO, X.V. Identidade e memória na comunidade israelita de Lisboa. Lisboa, 2004. Tese (Mestrado em Ciências Sociais) - ICS-IUL.

CENTRO ROGER IKOR (CRI) Seitas religiosas. Um guia sobre as falsas religiões para as conhecer e defender-se delas. Mem Martins: Editorial Inquérito, 1996.

COSTA, A.P.L. Sou ismaili, mas isso não me impede de ser português de gema: contributos da religião para os percursos e estratégias de inserção diferenciada dos ismailis em Portugal. Lisboa, 2007. Tese (Mestrado em Migrações, Minorias Étnicas e Transnacionalismo) - FCSH-UNL.

CRUZ, M.B. O Estado Novo e a Igreja Católica. Lisboa: Bizâncio, 1999.

CURTINHAL, E.M.A. “Deus É Brasileiro”. Vivências religiosas e o quotidiano entre imigrantes brasileiros católicos e evangélicos. Lisboa, 2008. Tese (Mestrado em Antropologia) - ISCTE-IUL.

DAVIE, G. Religion in Britain: a persistent paradox. Oxford: Wiley-Blackwell, 2015. 
DAVIE, G. Religion in Europe in the $21^{\text {st }}$ century: the factors to take into account.

European Journal of Sociology/Archives Européenes de Sociologie, v. 47, n. 2, p. 271-296, 2006.

DIAS, J.I.G.C. Representações de comportamentos apropriados-inapropriados e metáfora de "adulto adaptado" em pais muçulmanos residentes na área da Grande Lisboa, com filhos dos 5-12 anos. Lisboa, 2010. Tese (Mestrado em Educação) - IE-UL.

DOBBELAERE, K. Towards an integrated perspective of the processes related to the descriptive concept of secularization. Sociology of Religion, v. 6o, n. 3, p. 229-247, 1999.

DOBBELAERE, K. Trend report: Secularization: a multi-dimensional concept. Current Sociology, v. 29, n. 2, p. 3-153, 1981.

FERNANDES, A.T. Da desregulamentação institucional à diluição do crer. In: PINTO, J.M.; PEREIRA, V.B. (orgs.). Desigualdades, desregulação e riscos nas sociedades contemporâneas. Porto: Afrontamento, 2008, p. 173-208.

FERNANDES, C.A.S. Solidariedade prática. As relações de apoio entre a comunidade islâmica de Lisboa e os guineenses. Lisboa, 2015. Dissertação (Mestrado em Estudos Africanos) - ISCTE-IUL.

FONSECA, P.D.M. Bancos de igreja: de esquecidos, a estranhamente aquecidos: uma comunidade protestante em mudança no coração do Porto. Porto, 2015. Dissertação (Mestrado em Sociologia) - FL-UP.

FORMENTI, A. Going for God: mobility, place and temporality among Evangelical Guineans in Lisbon. Lisboa, 2014. Tese (Doutoramento em Antropologia) - ICS-UL.

GALHARDO, M.R.F.S. Vivências conjugais: diferenças e semelhanças entre casais católicos e casais hindus. Porto, 2005. Dissertação (Mestrado em Psicologia) - FPCE-UP.

GRACINO, P. Jesus made in Brazil: notas sobre a transnacionalização do pentecostalismo brasileiro para Portugal. Horizonte, v. 9, n. 22, p. 416-445, 2011.

HERVIEU-LÉGER, D. O peregrino e o convertido: a religião em movimento. Lisboa: Gradiva, 2005.

IANNACCONE, L.R. Religious markets and the economics of religion. Social Compass, v. 39, n. 1, p. 123-131, 1992.

INSTITUTO NACIONAL DE ESTATÍSTICA (INE). Censos 2o11. XV Recenseamento Geral da População. V Recenseamento Geral da Habitação. Resultados definitivos Portugal. Lisboa: INE, 2012.

LAGES, M. Elementos para uma tipologia sociológica do Cristianismo português. Ora et Labora, v. 12, n. 3, p. 200-231, 1965. 
LEITE, R.M. Polaridades do campo protestante em Portugal. In: TEIXEIRA, A. (org.). Identidades religiosas em Portugal: ensaio interdisciplinar. Lisboa: Paulinas, 2012, p. 255-286.

LOURENÇO, I. Os corpos da Devi: religião e género em diáspora. Lisboa, 2009. Tese (Doutoramento em Antropologia) - ISCTE-IUL.

LUCKMANN, T. The invisible religion. The problem of religion in modern society. New York (NY): Macmillan, 1967.

MACHADO, S.C.D. À descoberta da comunidade muçulmana do Porto: relatório do estágio realizado no SOS Racismo. Porto, 2012. Dissertação (Mestrado em História, Relações Internacionais e Cooperação) - FL-UP.

MAFRA, C. Na posse da palavra: religião, conversão e liberdade pessoal em dois contextos. Lisboa: ICS, 2002.

MAPRIL, J. Aren't you looking for citizenship in the wrong place? Islamic education, secular subjectivities and the Portuguese Muslim. Religion and Society: advances in research, v. 5, p. 65-82, 2014.

MAPRIL, J. 'Bons' muçulmanos: Educação islâmica e cidadania na Área Metropolitana de Lisboa. In: VILAÇA, H.; PACE, E. (orgs.). Religião em Movimento. Imigrantes e diversidade religiosa em Portugal e Itália. Porto: Estratégias Criativas, 2010, p. 37-54.

MAPRIL, J. Islão e transnacionalismo: Uma etnografia entre Portugal e o Bangladesh. Lisboa: ICS, 2012a.

MAPRIL, J. Será que deus não precisa de passaporte? Islão 'imigrante', normatividades seculares e islamofobia. In: DIAS, N.; DIAS, B. (eds.). Imigração e racismo: O lugar do outro. Lisboa: Edições 70/Le Monde Diplomatique, 2012b, p. 137-152.

MAPRIL, J; SOARES, P.; ALMODOVAR, L. Portugal. In: SCHARBRODT, O. et al. (eds.). Yearbook of Muslims in Europe - Vol. 9. Leiden: Brill, 2017, p. 536-550.

MARQUES, A.S. A Igreja Adventista do Sétimo Dia numa perspectiva de difusão geográfica no território português. Coimbra, 2011. Dissertação (Mestrado em Geografia Humana) - FL-UC.

MARQUES, V.L.M. Sobre práticas religiosas e culturais islâmicas no Brasil e em Portugal: notas e observações de viagem. Belo Horizonte, 2009. Tese (Doutorado em Sociologia) - Universidade Federal de Minas Gerais.

MONTEIRO, T.L. Dinâmica social e religião. In: TEIXEIRA, A. (org.). Identidades religiosas em Portugal: ensaio interdisciplinar. Lisboa: Paulinas, 2012a, p. 69-129.

MONTEIRO, T.L. Famílias e novos movimentos religiosos: trajectória familiar, individualização e identidade espiritual. Lisboa, 2005. Tese (Doutoramento em Sociologia) - ISCTE-IUL. 
MONTEIRO, T.L. Grupos ligados à tradição milenarista e apocalíptica cristã. In: TEIXEIRA, A. (org.). Identidades religiosas em Portugal: ensaio interdisciplinar. Lisboa: Paulinas, 2012b, p. 307-313.

MONTEIRO, T.L. Minorias religiosas e fluxos migratórios: hindus, chineses, cristãos de rito oriental. In: TEIXEIRA, A. (org.). Identidades religiosas em Portugal: ensaio interdisciplinar. Lisboa: Paulinas, 2012c, p. 315-324.

MONTEIRO, T.L. Novas orientações religiosas e espirituais. In: TEIXEIRA, A. (org.). Identidades religiosas em Portugal: ensaio interdisciplinar. Lisboa: Paulinas, 2012d, p. 325-332.

\section{NUNES, T.R.R.C.B. Dimensões de socialização implicadas na vida religiosa da} comunidade chinesa do templo Fo Guang Shan de Lisboa. Lisboa, 2014. Dissertação (Mestrado em Estudos Orientais - China) - FCH-UCP.

OLIVEIRA, M.J. Espaços de religiosidade no Porto : o seu papel na integração dos imigrantes brasileiros. Sociologia, Número temático: Imigração, diversidade e convivência cultural, p. 211-234, 2012.

OLIVEIRA, M.J. Os imigrantes brasileiros no Grande Porto: mobilidade social e apropriações espaciais. Porto, 2013. Tese (Doutoramento em Sociologia) - FL-UP.

PAULA, T.M. Relação entre conservadorismo protestante, estilos parentais e bem-estar psicológico. Lisboa, 2012. Tese (Mestrado em Psicologia) - FP-UL.

PIGNATELLI, M. A Comunidade israelita de Lisboa. O passado e o presente na construção da etnicidade dos judeus de Lisboa. Lisboa, 2000. Dissertação (Mestrado em Ciências Antropológicas) - ISCSP-UTL.

PIGNATELLI, M. Interioridades e exterioridades dos judeus de Lisboa. Lisboa, 2008. Tese (Doutoramento em Ciências Sociais - Antropologia Cultural) - ISCSP-UTL.

PORDEUS JR, I. Portugal em transe. Transnacionalização das religiões afro-brasileiras: conversão e performances. Lisboa: ICS, 2009.

RAFAEL, I.A. Género, trabalho e religião: dinâmicas quotidianas de mulheres hindus na gestão do equilíbrio trabalho-família. Lisboa, 2018. Dissertação (Mestrado em Migrações, Inter-etnicidades e Transnacionalismo) - FCSH-UNL.

RAMOS, M.R. Missionários do sul: evangelização, globalização e mobilidades dos pastores cabo-verdianos da Igreja do Nazareno. Lisboa, 2015. Tese (Doutoramento em Antropologia) - ICS-IUL.

RIBEIRO, F.P.B. Normais laborais e liberdade de prática religiosa: o caso dos crentes do islão em Portugal. Lisboa, 2010. Tese (Mestrado em Migrações, Interetnicidades e Transnacionalismo) - FCSH-UNL.

RIIS, O. Modes of religious pluralism under conditions of globalisation. International Journal on Multicultural Societies, v. 1, n. 1, p. 20-34, 1999. 
RODRIGUES, D. Etnicidade cigana e religião: a Igreja Evangélica de Filadélfia de Portugal. In: MENDES, M.; MAGANO, O. (orgs.). Ciganos portugueses: Olhares plurais e novos desafios numa sociedade em transição. Lisboa: Mundos Sociais, 2013, p. 93-110.

RODRIGUES, D. Pentecôtisme et identité tsigane: le cas de l'Église Évangelique de Philadelphie du Portugal. Lusotopie, v. XIII, n. 1, p. 85-93, 2006.

RODRIGUES, D.; GUERREIRO, T. O Pentecostalismo na Serra da Estrela: conversão, batismo e identidade religiosa na Assembleia de Deus da Covilhã (Portugal).

Observatório da Religião, v. 2, n. 2, p. 108-129, 2015.

RODRIGUES, D.; SANTOS, A.P. Grupo social, género e família na etnia cigana: o caso dos ciganos evangélicos. In: BASTOS, S.; BASTOS, J.G.P. (coords.). Filhos diferentes de deuses diferentes. Lisboa: ACIME, 2006, p. 189-203.

RUUTH, A.; RODRIGUES, D. (1999). Deus, o demónio e o homem: o fenómeno Igreja Universal do Reino de Deus. Lisboa: Colibri, 1999.

SANT'ANA, H.M. Migrantes hindus em Portugal: trajectos, margens e poderes. Lisboa, 2008. Tese (Doutoramento em Antropologia) - ISCTE.

SANTOS, H.R.G. Jovens muçulmanos, identidades e escola pública: um estudo de caso. Coimbra, 2008. Dissertação (Mestrado em Sociologia) - FE-UC.

SANTOS, J.R.A. Religião no feminino: experiências da "mulher Kimbanguista” em Portugal. Lisboa, 2010. Dissertação (Mestrado em Antropologia) - ISCTE-IUL.

SANTOS, L.A. O judaísmo no campo religioso português contemporâneo. In: TEIXEIRA, A. (org.). Identidades religiosas em Portugal: ensaio interdisciplinar. Lisboa: Paulinas, 2012, p. 133-145.

SANTOS, L.A. Pluralidade religiosa: correntes cristãs e não cristãs no universo religioso português. In: AZEVEDO, C.M. (dir.). História religiosa de Portugal - Volume 3: Religião e secularização. Lisboa: Círculo de Leitores, 2002, p. 399-501.

SARAIVA, C. African and Brazilian altars in Lisbon: Some considerations on the reconfigurations of the Portuguese religious field. In: NARO, N.P.; SANSI-ROCA, R.; TREECE, D.H. (eds.). Cultures of the lusophone black Atlantic. New York (NY): Palgrave Macmillan, 2007, p. 175-196.

SARAIVA, C. Afro-Brazilian religions in Portugal: bruxos, priests and pais de santo. Etnográfica, v. 14, n. 2, p. 265-288, 2010.

SARAIVA, C. Blood, sacrifices and religious freedom: Afro-Brazilian associations in Portugal. In: BLANES, R. Blanes; MAPRIL, J. (eds.). Sites and politics of religious diversity in Southern Europe. The best of all gods. Leiden: Brill, 2013, p. 129-154.

SARAIVA, C. Energias e curas: a umbanda em Portugal. Revista Pós Ciências Sociais, v. 8, n. 16, p. 55-76, 2011. 
SARAIVA, C. Pretos velhos atravessando o Atlântico: religiões afro-brasileiras em Portugal. In: ROCHA, C.; VASQUEZ, M. (eds.). A diáspora das religiões brasileiras. São Paulo: Editora Ideias e Letras, 2016, p. 197-222.

SARAIVA, C. Ter o seu corpo morto aqui ou lá: transnacionalismos funerários entre imigrantes da Guiné-Bissau em Portugal. Debates do NER, v. 2, n. 28, p. 153-176, 2015.

SARAIVA, C. Transnational migrants and transnational spirits: An African religion in Lisbon. Journal of Ethnic and Migration Studies, v. 34, n. 2, p. 253-270, 2008.

SARRÓ, R. Kongo en Lisboa: Um ensayo sobre la reubicación y la extraversión religiosa. In: AIXELÀ, Y.; MALLART, L.; MARTÍ, J. (eds.). Introducción a los estudios africanos. Barcelona: CEIBA, 2009, p. 115-129.

SARRÓ, R.; BLANES, R.L. Profetas e missionários: reflexões sobre as igrejas angolanas em Lisboa. In: VILAÇA, H.; PACE, E. (eds.). Religião em movimento: imigrantes e diversidade religiosa em Portugal e Itália. Porto: Estratégias Criativas, 2010, p. 141-154.

SARRÓ, R.; MÉLICE, A. Kongo-Lisbonne: dialectique du centre et de la périphérie dans l'Église Kimbanguiste. Canadian Journal of African Studies, v. 46, n. 3, p. 1-17, 2012.

SARRÓ, R.; SANTOS, J. Gender and return in the Kimbanguist Church of Portugal. Journal of Religion in Europe, v. 4, n. 3, p. 369-387, 2011.

SARRÓ, R; BLANES, R.L. O Atlântico cristão: Apontamentos etnográficos sobre o encontro religioso em Lisboa. In: CABRAL, M.V.; WALL, K.; ABOIM, S.; SILVA, F.C. (eds.). Itinerários: A Investigação nos 25 Anos do ICS. Lisboa: ICS, 2008, p. 839-854.

SILVA, N.C.N. Os ismailis e os lisboetas: duas faces da mesma moeda. Lisboa, 2011. Dissertação (Mestrado em Comunicação, Cultura e Tecnologias de Informação) - ISCTEIUL.

SOBROSA, A.A. Da aflição à comunhão: um estudo etnográfico no templo de umbanda Pai Oxalá e Mamãe Iansã. Coimbra, 2009. Dissertação (Mestrado em Antropologia Social e Cultural) - FCT-UC.

SOUSA, M.T.; RODRIGUES, D. O sexto sentido e a sexta-feira 13: narrativas da Igreja Universal em um programa televisivo da Rede Record em Portugal. Palabra Clave, v. 18, n. 2, p. 563-587, 2015 .

SOUZA JR, P.G. "Fluxos e fronteiras": mapeando o pentecostalismo brasileiro em Portugal. Civitas - Revista de Ciências Sociais, v. 14, n. 3, p. 484-506, 2014.

STARK, R.; FINKE, R. Acts of faith. Berkeley and Los Angeles (CA): University of California Press, 2000.

SWATOWISKI, C.W. Igreja Universal em Portugal: tentativas de superação de um estigma. Intratextos, Número especial 01, p. 169-192, 2010. 
TÉCHIO, K.H. Transformando a água em sangue: uma análise sobre a exportação evangélica brasileira através das performances da IPDA. Lisboa, 2011. Dissertação (Doutoramento em Antropologia) - FCSH-UNL.

TEIXEIRA, A.C. História do budismo em Portugal e da União Budista Portuguesa. Revista Lusófona de Ciência das Religiões, n. 11, p. 225-244, 2007.

TIESLER, N.C. Novidades do terreno. Muçulmanos na Europa e o caso português. Análise Social, v. XXXIX, n. 173, p. 827-849, 2005.

TIESLER, N.C.; CAIRNS, D. Across difference: Portuguese Muslim youth as Portuguese youth? In: CAIRNS, D. (ed.). Youth on the move: European youth and geographical mobility. Morlenbach: VS Verlag, 2010, p. 107-115.

TIESLER, N.C.; CAIRNS, D. Representing Islam and Lisbon youth: Portuguese Muslims of Indian-Mozambican origin. Lusotopie, v. XIV, n. 1, p. 223-238, 2007.

TROVÃO, S. Parental transmission of religion and citizenship among migrant Muslim families settled in Mozambique, Portugal, United Kingdom and Angola. Journal of Muslim Minority Affairs, v. 37, n. 2, p. 129-146, $2017 \mathrm{a}$.

TROVÃO, S. Religion and civic participation among the children of immigrants: insights from the postcolonial Portuguese context. Journal of Ethnic and Migration Studies, v. 38, n. 5, p. 851-868, 2012.

TROVÃO, S. Religion and the intergenerational dynamics of citizenship: a comparison between African and Indian migrant families. European Journal of Women's Studies, v. 24, n. 3, p. 266-280, 2017b.

TROVÃO, S.; RAMALHO, S.; BATORÉU, F. Managing work and family life through religious participation: A comparative approach between Muslim, Hindu and Christian migrant women in Lisbon, Portugal. AG About Gender - Rivista internazionale di studi di genere, v. 3, n. 6, p. 116-138, 2014.

TROVÃO, S.; RAMALHO, S.; DAVID, I. Mental health among Asian and African migrant working mothers: new vulnerabilities, old religious coping resources. Mental Health, Religion \& Culture, v. 20, n. 2, p. 162-174, 2017.

TROVÃO, S.S.; RAMALHO, S.C.C.; DAVID, M.I.P.T. Transnational families, religious participation and gender dynamics: Filipino, Sao Tomean and Indo-Mozambican immigrant women in Lisbon, Portugal. Gender, Place and Culture: A Journal of Feminist Geography, v. 22, n. 3, p. 325-343, 2015.

VAKIL, A. Comunidade islâmica em Portugal. In: CRISTÓVÃO, F. (dir.). Dicionário temático da lusofonia. Lisboa: Associação de Cultura Lusófona/Texto Editores, 2005, p. 186-189.

VILAÇA, H. A religião na cidade: territórios, materialidades e comunicação. Sociologia, Número temático: processos sociais e questões sociológicas, p. 12-27, 2017. 
VILAÇA, H. Da Torre de Babel às terras prometidas. Pluralismo religioso em Portugal. Porto: Afrontamento, 2006.

VILAÇA, H. Dinâmicas identitárias e performances dos protestantes e evangélicos em Portugal. Humanística e Teologia, v. 36, n. 2, p. 63-76, 2015.

VILAÇA, H. Imigração, etnicidade e religião: o papel das comunidades religiosas na integração dos imigrantes da Europa de Leste. Lisboa: ACIDI, 2008.

VILAÇA, H. Novas paisagens religiosas em Portugal: do centro às margens. Didaskalia, v. XLIII, n. 1/2, p. 81-114, 2013.

VILAÇA, H. Para lá da etnicidade: as comunidades religiosas dos imigrantes de leste em Portugal. In: VILAÇA, H.; PACE, E. (eds.). Religião em movimento: imigrantes e diversidade religiosa em Portugal e Itália. Porto: Estratégias Criativas, 2010, p. 73-91.

VILAÇA, H. Territorialidades religiosas em Portugal. Mediações, v. 21, n. 2, p. 197-217, 2016. 